\title{
Simulation-based service walkthrough (SBSW) to assess airport environment performance
}

Irem Caglayan and Yasemin Afacan

Department of Interior Architecture and Environmental Design, Bilkent University, Ankara, Turkey

\begin{abstract}
Purpose - The increasing number of older passengers is resulted in a growing significance of international senior tourism industry. In today's competitive airport environments, improving the airport service performance (ASP) for older passengers is crucial to take an important place in the market. ASP design has been in the focal point of many researchers and airport stakeholders. However, the service performance evaluation regarding airport architectural design and use of older passengers have been mostly underrated. Design/methodology/approach - The study focused on ASP evaluation of architectural building elements. The proposed simulation-based service walkthrough (SBSW) was applied in a case airport building in Istanbul. Experts performed landside passenger activities to evaluate its ASP with a given walkthrough instruction. An empathic tool, GERonTologic age simulation (GERT) suit, was used to experience the physical limitations of older passengers during the experiment.

Findings - Results showed that SBSW positively influenced experts' evaluation of ASP, where higher service problems were obtained. The GERT suit created a significant difference, where lower ASP scores and higher perceived empathy were observed within the group with the GERT suit. The study concluded that the proposed ASP criteria and SBSW could provide a useful research framework during service design of agefriendly airports.

Originality/value - The study addressed a novel area of enquiry by proposing a new set of ASP criteria for older passengers considering the airport architectural design and evaluating these criteria through a new empathic approach "SBSW".
\end{abstract}

Keywords Airport service performance, Airport design, Age simulation suit, Design for older passengers, Service walkthrough

Paper type Research paper

$\begin{array}{ll}\text { Abbreviations } & \\ \text { ASP } & \text { airport service performance } \\ \text { EBIPMs } & \text { equal based indicator performance models } \\ \text { GERT } & \text { GERonTologic age simulation } \\ \text { SBSW } & \text { simulation-based service walkthrough } \\ \text { WBIPM } & \text { weight-based indicator performance models } \\ \text { PSBS } & \text { passenger satisfaction benchmarking surveys }\end{array}$

\section{Introduction}

Air travel is the mode of transportation of the 21st century, in which airports are the crucial part of the air transport system (Edwards, 2005). In recent years, there is great competition among airports and airlines as a result of deregulation and growing passenger awareness

This study was conducted as a part of Ph.D. thesis of the first author in Bilkent University, in the Department of Interior Architecture and Environmental Design. The financial support for this study was supported by the grant of Science Academy's Young Scientist Award Program 2017 (BAGEP) received by the second author. The authors thank study participants and acknowledge their contributions.

\section{environment} performance

Received 29 December 2020 Revised 18 March 2021 30 March 2021 15 April 2021 Accepted 16 April 2021

(a) 
$\mathrm{ARCH}$ 15,3

906 about the service quality. Airports and airlines are trying to attract more passengers by giving high-quality services (Chang and Chen, 2012). As a consequence of increasing pressure for improving airport service quality, airport stakeholders encounter conflicting objectives and complex performance aspects (Bezerra and Gomes, 2015). Therefore, identifying, assessing and monitoring performance criteria are becoming increasingly crucial for diverse stakeholders. The quality of airport service performance (ASP) also have a critical impact on promoting future tourism, as well as discouraging business tourism activities (Chang and Chen, 2012), so that assessment of ASP has become as a key determinant for the success of airport management (Yeh and Kuo, 2003).

With this growing competition, a comprehensive understanding of demographic differences is inevitable regardless of age and ability of all stakeholders and passengers engaged in the tourism sectors (Kohijoki and Marjanen, 2013). Studies have recently emphasized that senior tourism will become a major power for future international tourism as a result of globally ageing populations (Namkung and Jang, 2009). Thus, many tourism studies showed the growing significance of the senior international tourism market (Oh et al., 2002). Within this framework, understanding senior tourism and older passengers is becoming increasingly important for the international tourism industry allowing number of commercial and operational applications regarding airlines and airports (Burghouwt et al., 2006). Airlines considered older passengers as an important revenue source, and they provided price advantages as "senior discount" or “over 65 fares" (Graham et al., 2019). In the literature, older adults have expressed their desire for travelling, especially with air travel. However, as a result of the ageing process, they face many challenges in all stages and contexts that can result in negative air travel experiences (da Silva et al., 2018). Considering the limitations of older passengers, a strategic and systematic planning process is required to meet their specific needs, demands and expectations.

Despite the increasing importance of older passengers for airport terminals, a little research has been done to determine their needs based on the service quality (Chang and Chen, 2012; Graham et al., 2019). Currently, the role of airport architectural elements and the passenger experience on the service performance are only partially recognized. To fill this research gap, this study makes a unique contribution by emphasizing the airport service complexity and diversity from the perspective of older passenger experience in a landside area of an airport environment. In this study, the main aim is to derive a set of ASP criteria for older passengers and to propose a new approach called "simulation-based service walkthrough (SBSW)" as a response to airport service challenges. Within the framework of this study, SBSW means using an age simulation suit to experience the service design during the walkthrough process of the airport. This new approach increases empathy and enables younger people to experience possible physical limitations of older people (Groza et al., 2017). The study hypothesized that SBSW enhances designers' engagement while evaluating the airport service design to obtain recommendations for the existing and future projects to support the user experiences of older passengers. To test this hypothesis, the study has the following two-research objectives: to propose an older passenger-driven ASP model and to implement the model by experts with an empathic simulation tool in a case airport environment.

\section{Background}

\subsection{Older passengers using airport services}

Older passengers mainly have been travelling since they were young, and they do not see the age factors as any kind of constraint for travelling (Ramos-Sesma et al., 2018). However, as a result of the ageing process, a general decline is expected in their physical (e.g. vision loss, hearing loss and reduced mobility), cognitive, physiological and sensory capabilities (Hino et al., 2020; Pereira et al., 2019). Therefore, older passengers could have both physical 
(wayfinding, orientation, etc.) and psychological (getting lost, fear, etc.) difficulties during their airport service experiences (Lee and Kline, 2011; Qing et al., 2020). Therefore, these kinds of difficulties may cause confusion and anxiety for the aging population, especially when trying to adapt to new situations and unfamiliar environments (McIntyre and Harrison, 2017).

The greatest challenges that older passengers face at airports are walking, waiting and wayfinding (da Silva et al., 2018; Graham et al., 2019). The reduced physical, cognitive and psychological capabilities have important impacts on their air travel experiences. Many older adults have difficulties in reading the flight information on screens and hearing the flight information announcements (Chang and Chen, 2012). Due to their reduced cognitive abilities in the ageing process, older passengers also have wayfinding problems. Lastly, as a result of their reduced physical strength and limited mobility, long walking distances and carrying heavy baggage can be challenging (Lee et al., 2017). These difficulties require both systematic and user-centred approach to meet the specific service needs of older passengers. Therefore, the success of the architectural design becomes very crucial to support the performance of airport service.

\subsection{Airport service performance (ASP) models}

Airport studies have been long interested in airport passenger terminal performance. There are various assessment models for airport terminals based on multiple levels of statistical approaches. Each assessment model has a different strategy to determine attribute weights of ASP. Wiredja et al. (2019) defined these models under the following three categories: (1) equal based indicator performance models (EBIPMs), (2) weight-based indicator performance models (WBIPMs) and (3) passenger satisfaction benchmarking surveys (PSBSs). In the first category, EBIPM, each evaluation criteria included in the model has an equal weight for passenger evaluation. While some of these models are composed of one-stage assessment procedure, such as the importance-performance analysis (IPA) (Jiang and Zhang, 2016), datamining technique (Bogicevic et al., 2013) and range-performance analysis (Mikulić and Prebežac, 2008), the others are conducted in multi-stage procedures, such as SERVQUAL (Parasuraman et al., 1988) and the common factor approach (Pabedinskaite and Akstinaite, 2014). In WBIPM, passengers determine the value of each evaluation criterion quantitatively based on multi-stage assessments, such as fuzzy multi-attribute decision-making (Yeh and Kuo, 2003) and the analytical hierarchy process (Correia and Wirasinghe, 2008). In the last category, PSBS, customized passenger surveys are used to evaluate airport performance (Airports Council International, 2008).

Although research on assessing airport service quality has developed over time, the objective models using analytic and simulation data analysis techniques lack the capability of emphatically measuring the service quality from the passengers' point of view tools (Wiredja et al., 2019). The Airports Council International (ACI) (2000) introduced a mixed scale to assess the airport service quality in consultation with 512 airport members. This scale is composed of 13 objectives and 38 subjective criteria. Accordingly, Magri and Alves (2005) assessed the service quality of airport by developing the mixed framework of ACI further with 36 criteria. Later, Erdil and Yildiz (2011) utilized 22 service criteria based on the SERVQUAL approach to evaluate the airport service quality. Liou et al. (2011) proposed a new method called dominance-based rough set approach (DRSA) to collect passenger perception about the airport service quality. Since there is no standard in these passenger perception models, further research has been developed by considering the functional zones of airports as the service quality determinant of passengers. Thereby, de Barros et al. (2007) separated the airport into the following six different zones; transit, restrooms, restaurant and bars, duty free shops, security and other facilities, where passenger experience on the level of service was identified based on sub-criteria. Similarly, Gonçalves and Caetano (2017) established 23 service criteria by classifying the airport terminal into

\author{
Airport \\ environment \\ performance
}


$\mathrm{ARCH}$ 15,3

908

the seven dimensions: access, check-in, security screening, airport facilities, orientation, comfort and services. Later, Eshtaiwi et al. (2018) divided airport service areas into the following five zones to quantify and estimate their service quality weights: passenger service, airside area, financial perspective, safety and security, and environmental. Lastly, Wiredja et al. (2019) developed a passenger-centred model and measured overall service performance based processing and non-processing domains. Processing domains are zones related to departure activities, whereas non-processing domains are zones associated with arrival activities.

To our knowledge, there is a gap in the ASP literature with regard to the performance measurement models based on the architectural design elements. To close this gap, this study considered architectural building elements of the landside of the airport terminals as the main dimensions to create the ASP criteria. These building elements were systematized based on Froyen's (2012) study into the six following categories: (1) access, (2) horizontal circulation, (3) vertical circulation, (4) resting facilities, (5) restrooms and (6) food and drink facilities. With reference to these six categories, the study proposed 16 main service criteria along $45 \mathrm{sub}$ criteria by extending age-friendly principles by the World Health Organization (WHO) (2007) and airport guidelines for the older adults by the National Research Council (US) (2014). In this study, each criterion has equal weight for the evaluation and different from the majority of earlier studies our set of criteria is evaluated by the experts.

\section{Method}

\subsection{Ethical and official permission statement}

All the experimental procedures were approved by the Bilkent University Institutional Ethical Review Board. All the study participants agreed and signed the informed consent form, which stated the purpose of the study, their involvement, risks and emergency procedures. The study was confidential, and the participants had the right to terminate their participation at any time. All the official permissions for each participant were also obtained from the airport administration and police headquarters before data collection.

\subsection{Study sample and settings}

In total, 48 experts were randomly selected from the database of Chamber of Architects and Interior Architects in Ankara and Istanbul, Turkey. The participation was voluntary. Both the objectives and procedure of the study were explained to the participants. The selection criteria for the study were as follows: (1) having already service design/disability/older adults knowledge, (2) having worked professionally in various airport projects in practice and (3) being of a normal body mass index and not having any disability. Consequently, regarding the availability at a given time and willingness to participate to the study, the experts were determined considering the inclusion criteria.

An empirical case study within a recently constructed airport building in Istanbul, Turkey, was carried out to test the ASP in the architectural design context. The airport is located in the north of central Istanbul. It was constructed as the largest airport in the world, with a capacity of 200 million annual passengers and 3,500 flights per day (Koseoglu et al., 2018). The airport includes three terminals, six runways with multiple buildings that are connected through walkways, sky-bridges or tunnels. It serves 249 international and 45 domestic flights in total, and it has an area of 76.5 million square metres (Koseoglu et al., 2018). The study was conducted on the landside of the domestic departures. Figure 1 illustrates the plan of the experimental area of the building. This airport was selected because of its large scale and its flight capacity. The airport is being used not only the older passengers but also diverse passenger profiles are using this airport. Accordingly, the effectiveness of the proposed ASP criteria can be investigated more deeply considering the scale and the crowdedness of this airport building. Such an evaluation process could make an important 


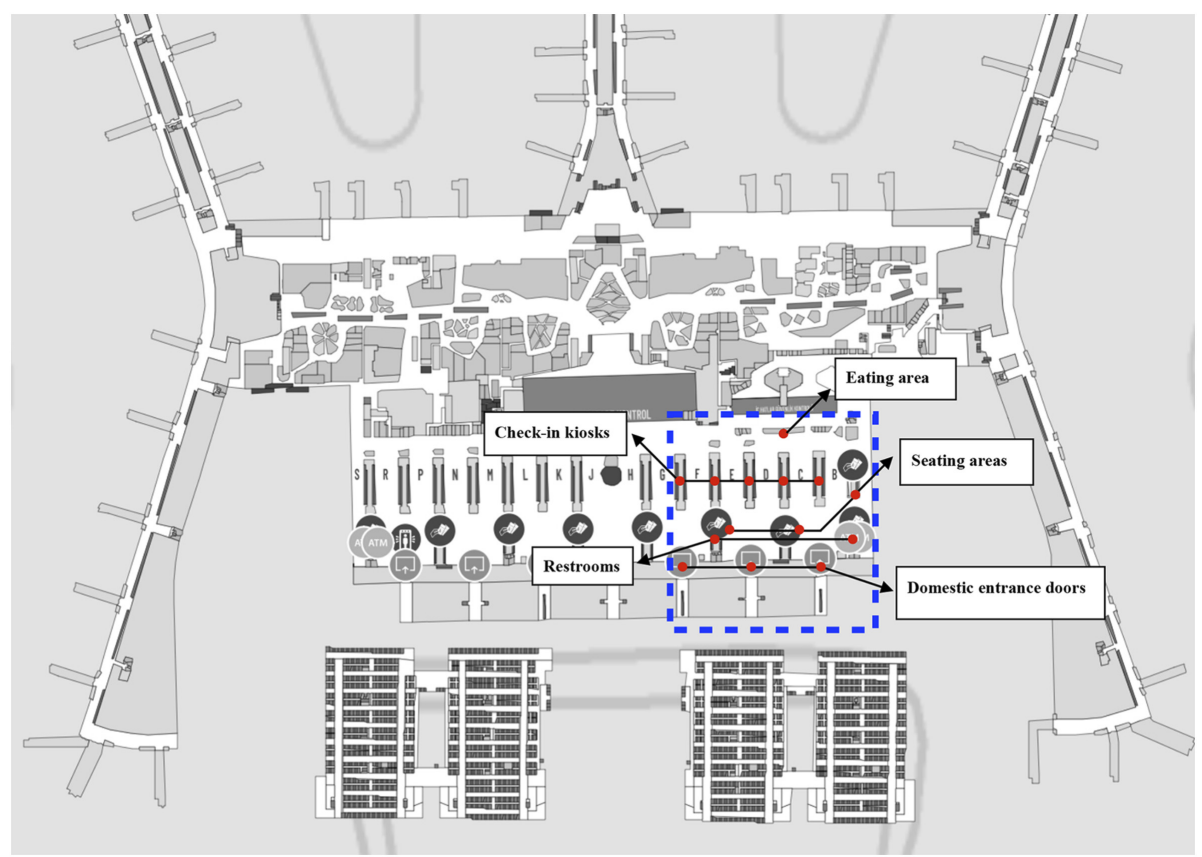

Airport
environment
performance

909

Figure 1.

The experimental area selected at the case airport building

contribution to the service design, as well as to the architectural design quality to support passenger-driven service performance.

\subsection{Tools}

3.3.1 Walkthrough method. One of the primary goals of user research in the field of service and architectural design is creating empathy with users (Zomerdijk and Voss, 2011). Kouprie and Visser (2009) emphasized that designers would rather prefer real material instead of sketches. Quicker immersion can be obtained through empathic tools like storytelling or personas. Empathy is commonly defined as the core for design process to understand how another person would walk in someone else's shoes (Kimbell and New, 2013). In the literature, various empathic design methods have been developed including observation (Swaranjali et al., 2021), experience prototyping (Buchenau and Suri, 2000), bodystorming (Burns et al., 1994), role playing games (Kaario et al., 2009) and service walkthroughs (Blomkvist and Bode, 2012).

This study used service walkthrough during the evaluation of the airport services. The service walkthrough is a service prototyping method that enables designers to put themselves in the shoes of the targeted user or customer group through a physical journey over space and time (Boletsis, 2018). It helps actors understanding a service more holistically. This method is originated from the combination of pluralistic walkthrough, bodystorming and experience prototyping in the way of increasing empathy with the targeted user groups (Arvola et al., 2013). Arvola et al. (2013) mentioned that even though service walkthroughs are experienced in the real world, some difficulties can be observed regarding truly feeling and experiencing the customer journey. Studies reported the need for more realistic service prototyping tools to address the limitations of the existing methods (Ilg et al., 2018). Thus, this 
$\mathrm{ARCH}$ 15,3

\section{0}

study proposes a new service walkthrough method by utilizing the age simulation suit to obtain a more realistic prototype of the older adults' body.

3.3.2 Age simulation suit. The concept of age simulation suit is relatively new and has been primarily used by the automotive industry. Automobile companies have created this suit to improve vehicle design for older drivers (Lavallière et al., 2017). Besides, the age simulation suit has also been used for educational purposes in nursery studies to enable students to experience challenges and needs of older adults (Russell, 2019). In these studies, this suit has been found very useful to increase empathy of nursery students towards older patients. Other related studies have generally considered only one part of the body, such as feet (Eymard et al., 2010), spine (Tremayne et al., 2011) and hands (Hall et al., 2010). In the field of environmental studies, Pastalan (1974) defined the empathic model as a conceptual approach and conducted experiments with $\mathrm{PhD}$ students of architecture, who wore simulators limiting their visual, hearing, respiratory and tactile capacities. More recently, Zijlstra et al. (2016) have evaluated the impact of age simulation suit on the performance of wayfinding in a hospital setting. However, research studies with the age simulation suit are rare in the field of service design.

The GERonTologic age simulation (GERT) suit was used in this study. The suit is produced in Niederstotzingen, Germany by Produkt + Projekt Wolfgang Moll Company (Groza et al., 2017). It enables young subjects to experience the physical limitations of older adults including limitations in vision, audition, mobility, balance, grip ability and strength (Zijlstra et al., 2016). It gives an opportunity to have a better understanding of older adults' behaviours and experience. GERT suit has four separate components, including (1) age simulation head, (2) age simulation torso, (3) age simulation legs and (4) age simulation arms (Plate 1). The age simulation head

Plate 1.

The main components of GERT suit, photo taken by the first author (2019)
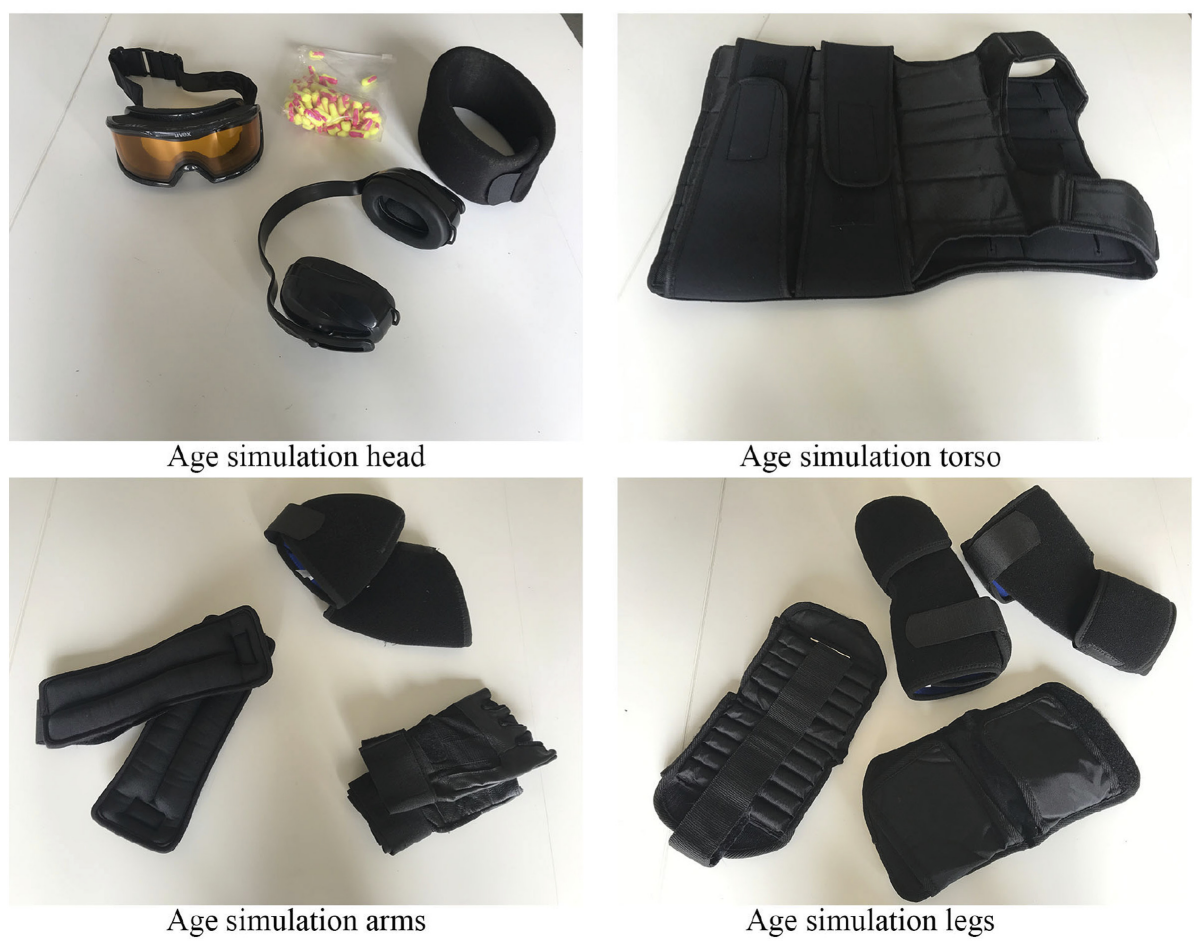
consists of special polycarbonate glasses (weight: $0.14 \mathrm{~kg}$ ) that cause changes in colour perception, grainy blurring, glare sensitivity and narrowed visual perception (Bouwhuis, 1992), hearing protectors (weight: $0.26 \mathrm{~kg}$ ) that cause high frequency hearing loss (Saup, 1993) and a neck collar that limits the neck mobility. The age simulation torso is comprised of a weight vest (weight: $10.10 \mathrm{~kg}$ ) that causes curvature of the spine, postural weakness, mobility restrictions and decreased balance (Zijlstra et al., 2016). The age simulation arms include elbow bandages around the elbows that reduce joint mobility, weight cuffs around the wrists (weight: $2 \times 1.50 \mathrm{~kg}$ ) that limit strength and coordination abilities and special gloves (weight: $0.12 \mathrm{~kg}$ ) that restrict hand mobility, grip ability and tactile perception (Saup, 1993). The age simulation legs consist of knee bandages around the knees to restrict joint mobility and weight cuffs around the ankles (weight: $2 \times 2.30 \mathrm{~kg}$ ) to cause reduction in strength, weaker coordination and unsteady gait (Platt, 1991).

\subsection{Experimental procedure}

The evaluation of the ASP is comprised of four sessions: pre-interview, SBSW, post-interview and empathy measurement (Figure 2). The interview questions were grouped under the six categories of building elements explained above that are related to the service performance of the case airport building. Before asking the questions, each expert was asked to do a movement tour of the building considering the airport use from the perspective of older passengers. The tour lasted ten minutes for each expert. Following the movement tour, six open-ended questions were asked, and their answers were sound recorded. The open-ended questions lasted approximately ten minutes for each expert. After finishing the open-ended questions, SBSW was started with an instruction in a story-telling format, where the experts had to perform a task for an imaginary flight ticket by performing airport processing and non-processing activities. The instruction was designed in such a way that the passengers had the opportunity to experience all the architectural building elements. The given instruction was as follows:

You are heading to Ankara where your daughter and your grandchild are living. You arrive at the terminal by using airport shuttles and the shuttle left you on Level -1 . You entered the airport from Door 1 located at Level 0 . You passed the first security control. You found the information about the Ankara flight from the flight information screens. You have to find check-in counter D12 for check-in and baggage claim. You have 1 hour until the boarding. You decided to buy a tea at the only coffee shop located in the landside domestic departures. You spend some time in the coffee shop sipping your tea. Before heading to the second security control, you decided to use the restrooms. You realized that you still have time until the boarding, so you wanted to find a seating element before passing the airside. After spending some time, you finally wanted to find the second securitycheckpoints.

During the service walkthrough, to evaluate the significance of GERT age simulation suit, 24 experts wore the suit and the other 24 did not. Photographs of the experts during service walkthrough were illustrated in Plate 2. Consistent with a real airport experience, all experts carried one baggage item. After finishing the walkthrough, experts were asked to rate their experience at each building element with the relevant ASP criteria. The ratings were in the form of five-point Likert scale (1: unacceptable, 2: poor, 3: fair, 4: good, 5: excellent). There were 45 sub-criteria in total. The reliability analysis of those 45 sub-criteria was calculated high (Cronbach's alpha $=0.963$ ). Walkthrough lasted approximately $40 \mathrm{~min}$ for each subject, and service evaluation took around $20 \mathrm{~min}$.

In the post-interview session, experts were asked to reconsider their pre-test statements with the same six open-ended questions in the pre-interview. Their answers were also sound recorded. More detailed ASP evaluations and further service problems were expected to be obtained during the post-interview compared to the pre-interview. Lastly, to evaluate the impact of GERT suit regarding the perceived empathy between the experts and older passengers, one last question was asked in the form of Inclusion of Other in the Self (IOS) 


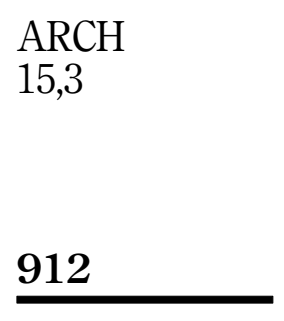

Figure 2.

The process diagram of the study, drawn by the first author (2020)

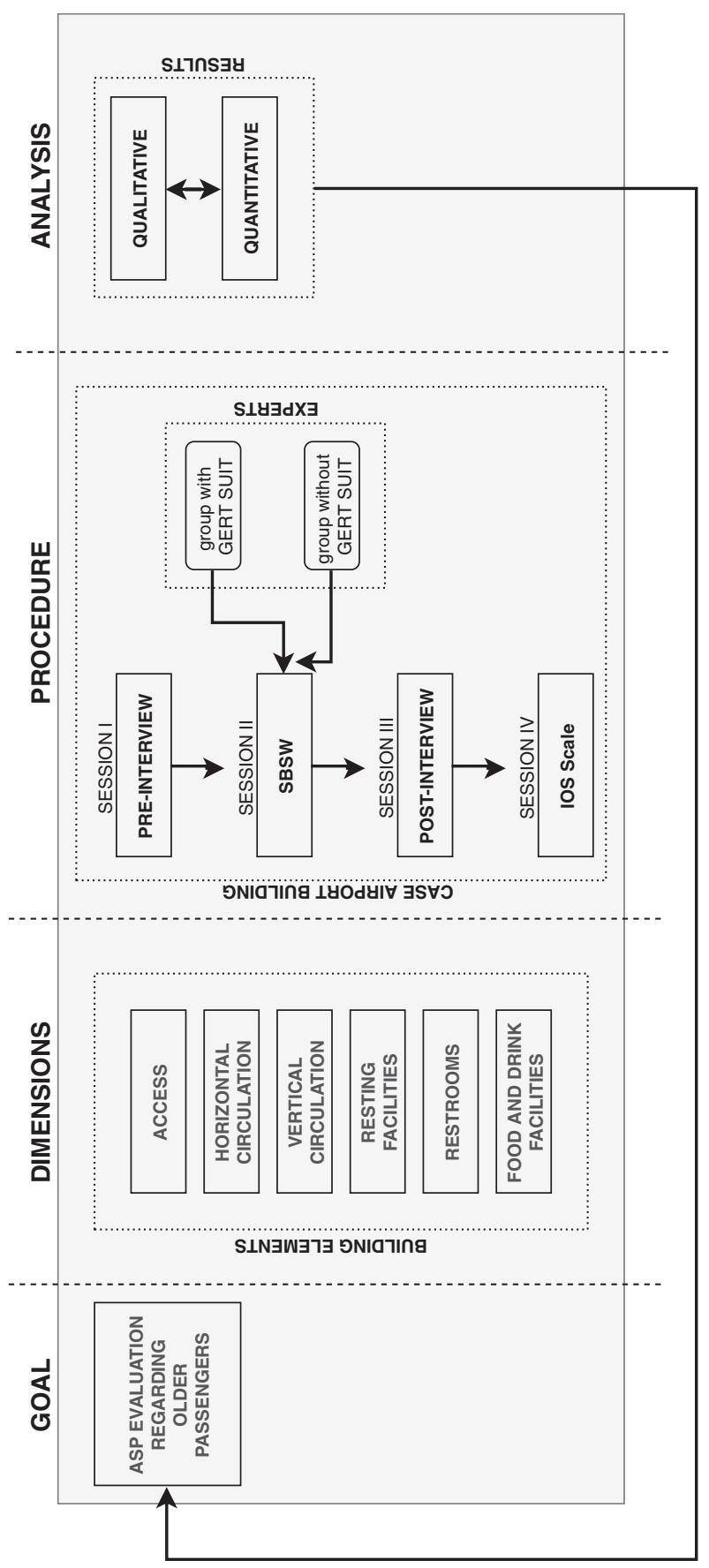


Scale, developed by Aron et al. (1992). The IOS scale helps to understand the perception of the experts towards older population, i.e. how close they feel with older adults.

\subsection{Data analysis}

The results of the study were analysed both qualitatively and quantitatively based on the older passenger-driven ASP model. The data obtained from the open-ended interviews were analysed qualitatively, whereas the Likert scale ratings of the ASP questions were analysed quantitatively. For the qualitative data analysis, the audio recordings of the participants during pre-interview and post-interview were translated. In total, 96 audio recordings in total were collected at the end of the two sessions. These audio recordings were analysed by the inductive content analysis that embodies open coding, creating categories and abstraction (Elo and Kyngäs, 2008). Each recording was listened through several times to enable content familiarization. As indicated by Elo and Kyngäs (2008), data from audio recordings were transcribed verbatim in the form of notes and headings as a process of open coding. The written text was read again and headings were obtained as much as possible to describe all aspects that had been mentioned by the experts. After this analysis, the following main categories were revealed considering the six building elements. Next, generic categories were freely generated by grouping the data under the main categories. All these processes of the content analysis were performed for pre-interview and post-interview separately. All quantitative data analyses were performed statistically by using IBM SPSS Statistics 24 software. The statistical calculations, descriptive analysis, independent $t$-tests, correlation matrices and multiple linear regression test were used for obtaining the results. All the statistical tests were performed at a significance level of 0.05 .

\section{Results}

\subsection{Descriptive statistics}

The majority $(72.91 \%)$ of the study experts were male. Their age range was between 29 and 49 years, with a mean age of 38.63 years. The experts were professionally working in the practice for at least six years. The professional experience of the experts was minimum six years and maximum 25 years, with a mean experience of 14.13 years.

\subsection{Abstraction processes}

As part of the inductive content analysis, two abstraction processes for the pre-interview and post-interview sessions were constructed regarding both the positive and negative ASP aspects of the case airport building. Figure 3 illustrates the abstraction process of the preinterview, and Figure 4 illustrates the abstraction process of the post-interview.
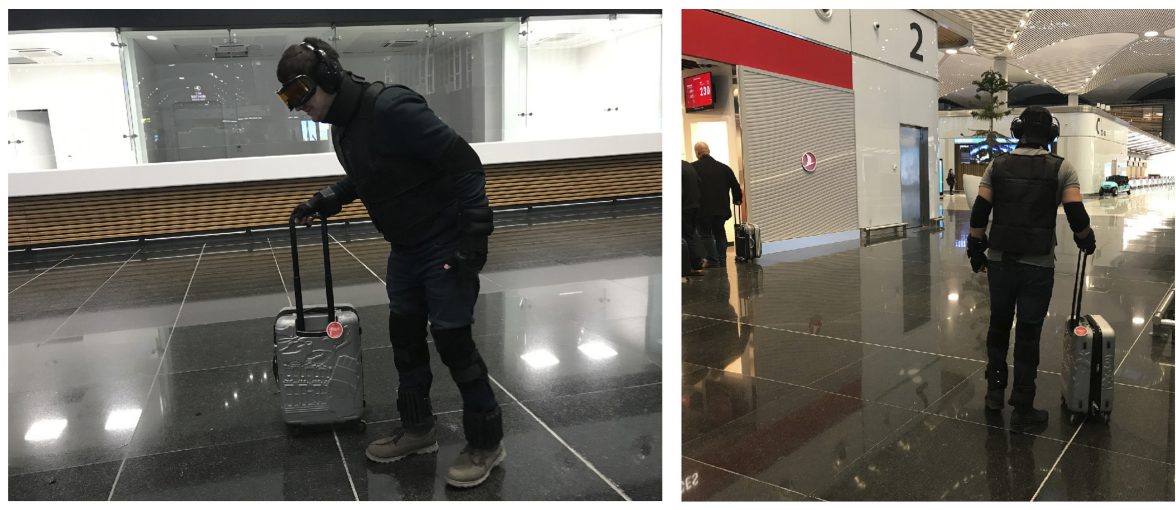

Plate 2.

Two of the experts who wore GERT suit during the experiment, photo taken by the first author (2019) 


\section{$\mathrm{ARCH}$}

15,3

\section{4}
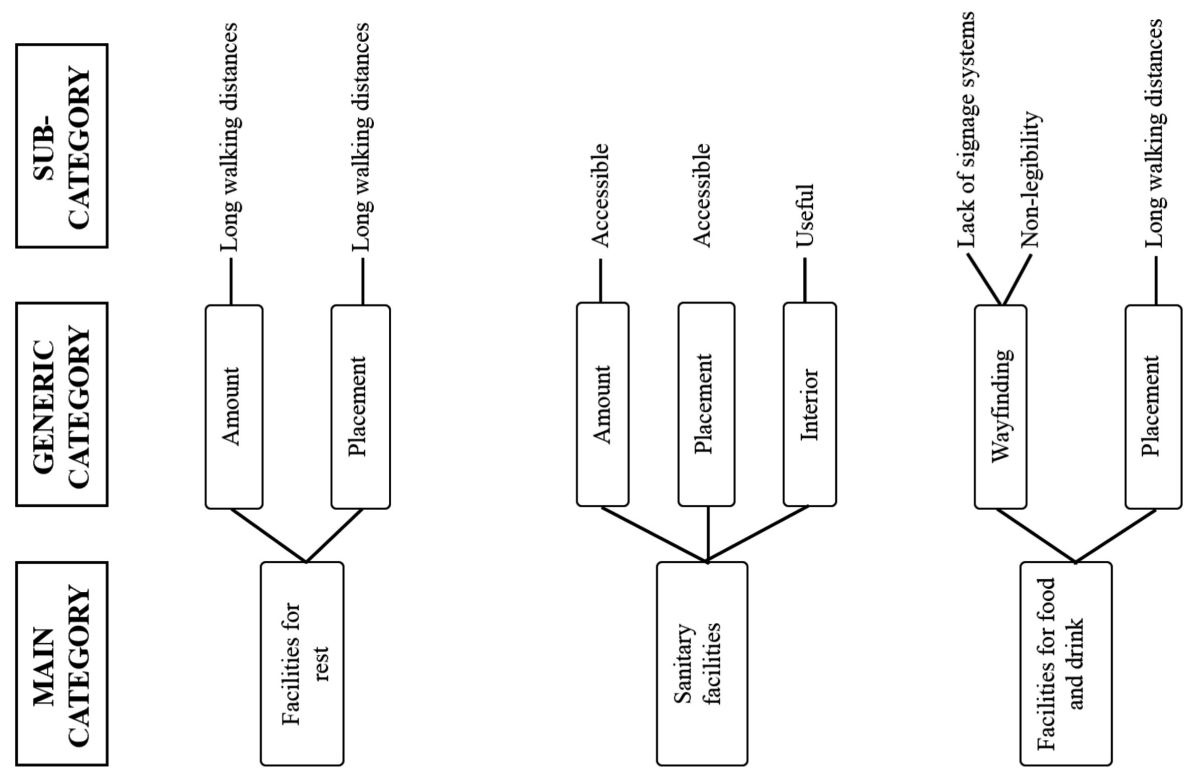

Figure 3.

The abstraction process of the pre-
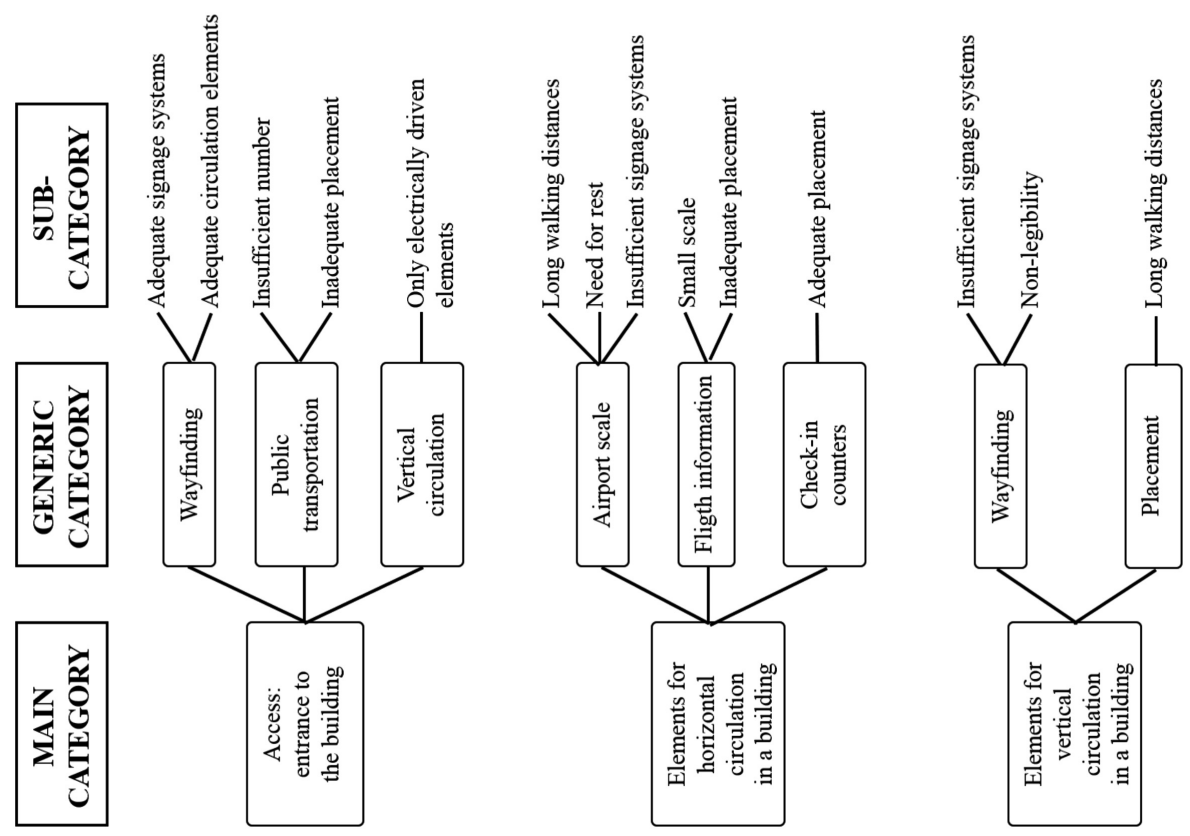
interview 


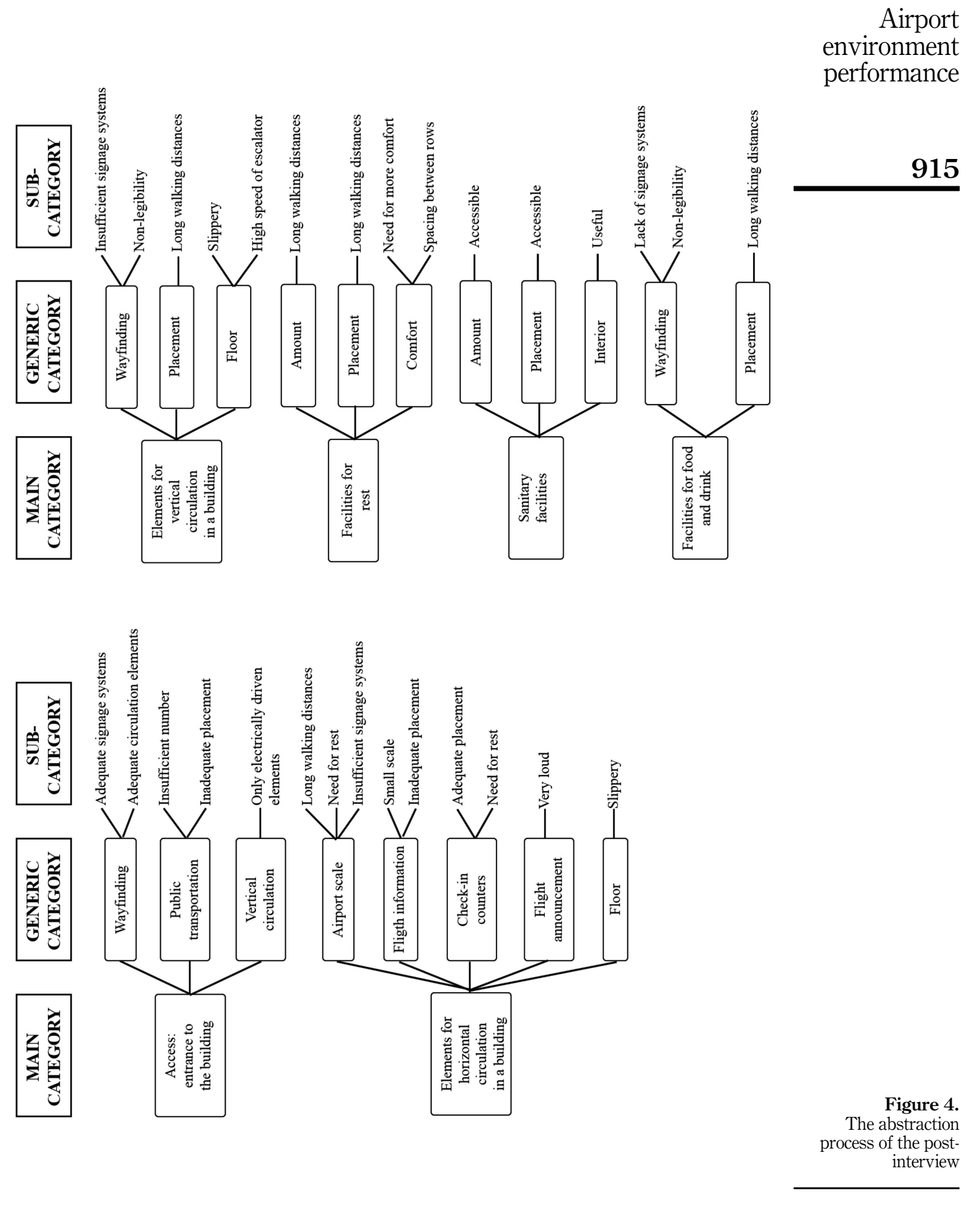


$\mathrm{ARCH}$ 15,3

\section{6}

Consequently, as shown in the Figures, the experts observed more service problems during the post-interview session compared to the pre-interview session.

\subsection{ASP evaluation}

The average mean response for each criterion was calculated. By observing the mean scores of the sub-criteria, $82.23 \%$ of the service attributes were evaluated at least as fair showing service criteria performance higher than three. Specifically, illumination levels are the most satisfactory service criteria at all of the building elements with mean scores higher than 4.5. Regarding the variability of the ASP, we can observe that the judgements are not very homogeneous; in fact, the standard deviation of the service performances vary from 0.463 to 1.488 (average value of 1.145). The average score of the overall service performance of the airport is 3.7851 referring to fair to good of the overall ASP. The lowest mean value belongs to "accessibility of the entrance from the public transportation" with a value of 2.25. Number of seating elements during horizontal circulation appeared as the second least successful service criteria with a mean value of 2.63. Regarding the building elements, the results were illustrated in Table 1. Restrooms found to have the highest ASP with a mean score of 4.1122. It means that restrooms can be indicated as having "good" ASP. On the other hand, other building elements showed similar means performance value that can be stated as having "fair" ASP. The results of the ASP evaluation were summarized in Table 2.

\subsection{The impact of GERT suit}

The $t$-test analyses were performed to analyse the influence of GERT suit during the simulation-based airport service assessment. The results showed a statistically significant difference between the two groups $(p=0.000)$. The mean values of the overall service performance of the airport for the group without the GERT suit is higher (4.2600) than the mean values of the group with the GERT suit (3.2750). Furthermore, the results showed statically significant mean differences for almost each building element (BE) except restrooms $(p(\mathrm{BE} 1)=0.002 ; p(\mathrm{BE} 2)=0.001 ; p(\mathrm{BE} 3)=0.002 ; p(\mathrm{BE} 4)=0.002 ; p(\mathrm{BE} 5)=0.012$; $p(\mathrm{BT} 6)=0.00)$. Since the restrooms found to have "good" ASP, both groups could easily perform their tasks in this building element, in which case no significant difference have been observed regarding to their ASP evaluations.

\subsection{The relative importance of each building element}

To assess the relative importance of each building element to the overall ASP, a multiple linear regression was performed. The six building elements were selected as the independent variables, and the building element performance of the building element was selected as the

\begin{tabular}{lllcr}
\hline & GERT & Mean & Std. deviation & Std. error mean \\
\hline (BE1) Access & Without GERT & 4.1750 & 0.26300 & 0.13150 \\
& With GERT & 3.4000 & 0.16330 & 0.08165 \\
(BE2) Horizontal circulation & Without GERT & 4.2850 & 0.31000 & 0.15500 \\
& With GERT & 3.3450 & 0.12014 & 0.06007 \\
(BE3) Vertical circulation & Without GERT & 4.3300 & 0.08981 & 0.04491 \\
& With GERT & 3.1950 & 0.42938 & 0.21469 \\
(BE4) Resting facilities & Without GERT & 4.0400 & 0.20928 & 0.10464 \\
& With GERT & 3.1250 & 0.28595 & 0.14297 \\
(BE5) Restrooms & Without GERT & 4.5550 & 0.20632 & 0.10316 \\
& With GERT & 3.6650 & 0.45317 & 0.22659 \\
(BE6) Food and drink facilities & Without GERT & 4.1900 & 0.16269 & 0.08134 \\
& With GERT & 2.9425 & 0.23936 & 0.11968
\end{tabular}

Table 1.

The ASP results for building elements and service sub-criteria 


\begin{tabular}{|c|c|c|c|c|c|}
\hline $\begin{array}{l}\text { Building } \\
\text { element }\end{array}$ & $\begin{array}{c}\text { Building element } \\
\text { performance }\end{array}$ & Sub-criteria for ASP & $\begin{array}{l}\text { Service criteria } \\
\text { performance }\end{array}$ & $\begin{array}{c}\text { Std. } \\
\text { deviation }\end{array}$ & $\begin{array}{r}\text { Airport } \\
\text { environment }\end{array}$ \\
\hline \multirow[t]{5}{*}{ Access } & \multirow[t]{5}{*}{3.7780} & $\begin{array}{l}\text { Security check-point design to avoid } \\
\text { long queues }\end{array}$ & 4.13 & 0.641 & \\
\hline & & $\begin{array}{l}\text { Accessibility of the entrance from the } \\
\text { public transportation }\end{array}$ & 2.25 & 0.707 & \\
\hline & & $\begin{array}{l}\text { Use of high-contrast colour } \\
\text { combinations of font, graphic and }\end{array}$ & 4.38 & 0.744 & 917 \\
\hline & & $\begin{array}{l}\text { background of the signage systems } \\
\text { Use of simple and meaningful icons } \\
\text { and plain language on the signage } \\
\text { systems }\end{array}$ & 4.50 & 0.535 & \\
\hline & & $\begin{array}{l}\text { Audible and understandable } \\
\text { announcements }\end{array}$ & 3.63 & 1.188 & \\
\hline \multirow{8}{*}{$\begin{array}{l}\text { Horizontal } \\
\text { circulation }\end{array}$} & \multirow[t]{8}{*}{3.8150} & Use of non-slippery flooring materials & 3.88 & 0.835 & \\
\hline & & $\begin{array}{l}\text { Placement of check-in kiosks to avoid } \\
\text { long walking distances }\end{array}$ & 3.00 & 0.926 & \\
\hline & & $\begin{array}{l}\text { Use of high-contrast colour } \\
\text { combinations of font, graphic and } \\
\text { background of the signage systems } \\
\text { and flight information screens }\end{array}$ & 4.38 & 0.744 & \\
\hline & & $\begin{array}{l}\text { Use of simple and meaningful icons } \\
\text { and plain language on the signage } \\
\text { systems }\end{array}$ & 4.50 & 0.535 & \\
\hline & & Placement of signage system & 3.75 & 1.035 & \\
\hline & & Illumination level & 4.75 & 0.463 & \\
\hline & & $\begin{array}{l}\text { Audible and understandable } \\
\text { announcements }\end{array}$ & 3.63 & 1.188 & \\
\hline & & Number of seating elements & 2.63 & 1.188 & \\
\hline \multirow{9}{*}{$\begin{array}{l}\text { Vertical } \\
\text { circulation }\end{array}$} & \multirow[t]{9}{*}{3.7667} & Use of non-slippery flooring materials & 3.63 & 0.916 & \\
\hline & & $\begin{array}{l}\text { Placement of elevators, stairs and } \\
\text { escalators to avoid long walking } \\
\text { distances }\end{array}$ & 2.75 & 1.165 & \\
\hline & & $\begin{array}{l}\text { Use of high-contrast colour } \\
\text { combinations of font, graphic and } \\
\text { background of the signage systems } \\
\text { (signs for elevators, stairs and } \\
\text { escalators) }\end{array}$ & 4.13 & 1.356 & \\
\hline & & $\begin{array}{l}\text { Use of simple and meaningful icons } \\
\text { and plain language on the signage } \\
\text { systems (signs for elevators, stairs and } \\
\text { escalators) }\end{array}$ & 4.25 & 0.463 & \\
\hline & & $\begin{array}{l}\text { Placement of signage system (signs for } \\
\text { elevators, stairs and escalators) }\end{array}$ & 2.75 & 1.488 & \\
\hline & & Illumination level & 4.63 & 0.518 & \\
\hline & & $\begin{array}{l}\text { Audible and understandable } \\
\text { announcements in the elevators }\end{array}$ & 3.63 & 1.188 & \\
\hline & & Speed of escalators & 3.50 & 1.195 & \\
\hline & & Visibility of elevator buttons & 4.63 & $\begin{array}{c}0.518 \\
\text { (continued) }\end{array}$ & $\begin{array}{r}\text { The ASP for each } \\
\text { building element } \\
\text { regarding GERT suit }\end{array}$ \\
\hline
\end{tabular}


$\mathrm{ARCH}$ 15,3

\begin{tabular}{|c|c|c|c|c|}
\hline $\begin{array}{l}\text { Building } \\
\text { element }\end{array}$ & $\begin{array}{l}\text { Building element } \\
\text { performance }\end{array}$ & Sub-criteria for ASP & $\begin{array}{l}\text { Service criteria } \\
\text { performance }\end{array}$ & $\begin{array}{c}\text { Std. } \\
\text { deviation }\end{array}$ \\
\hline \multirow[t]{6}{*}{$\begin{array}{l}\text { Resting } \\
\text { facilities }\end{array}$} & \multirow[t]{6}{*}{3.5850} & $\begin{array}{l}\text { Placement of seating elements to avoid } \\
\text { long walking distances }\end{array}$ & 2.75 & 1.035 \\
\hline & & Illumination level & 4.63 & 0.518 \\
\hline & & $\begin{array}{l}\text { Audible and understandable } \\
\text { announcements from the seating } \\
\text { elements }\end{array}$ & 3.88 & 0.991 \\
\hline & & Amount of seating elements & 2.75 & 1.165 \\
\hline & & Comfort of the seating elements & 3.75 & 0.707 \\
\hline & & $\begin{array}{l}\text { Spacing between rows of the seating } \\
\text { elements }\end{array}$ & 3.75 & 0.707 \\
\hline \multirow[t]{9}{*}{ Restrooms } & \multirow[t]{9}{*}{4.1122} & Use of non-slippery flooring materials & 3.63 & 0.744 \\
\hline & & $\begin{array}{l}\text { Placement of restrooms to avoid long } \\
\text { walking distances }\end{array}$ & 3.88 & 0.835 \\
\hline & & $\begin{array}{l}\text { Use of high-contrast colour } \\
\text { combinations of font, graphic and } \\
\text { background of the signage systems } \\
\text { (signs for restrooms) }\end{array}$ & 4.25 & 1.035 \\
\hline & & $\begin{array}{l}\text { Use of simple and meaningful icons } \\
\text { and plain language on the signage } \\
\text { systems (signs for restrooms) }\end{array}$ & 4.50 & 0.535 \\
\hline & & $\begin{array}{l}\text { Placement of signage system (signs for } \\
\text { restrooms) }\end{array}$ & 4.25 & 0.707 \\
\hline & & Illumination level & 4.50 & 0.535 \\
\hline & & $\begin{array}{l}\text { Audible and understandable } \\
\text { announcements }\end{array}$ & 3.75 & 1.035 \\
\hline & & $\begin{array}{l}\text { Ease of use for sanitary amenities } \\
\text { (sink, water closets etc.) }\end{array}$ & 4.00 & 0.926 \\
\hline & & Door heaviness & 4.25 & 0.886 \\
\hline \multirow[t]{8}{*}{$\begin{array}{l}\text { Food and } \\
\text { drink facilities }\end{array}$} & \multirow[t]{8}{*}{3.5625} & $\begin{array}{l}\text { Placement of food and drink facilities } \\
\text { to avoid long walking distances }\end{array}$ & 2.75 & 1.035 \\
\hline & & $\begin{array}{l}\text { Use of high-contrast colour } \\
\text { combinations of font, graphic and } \\
\text { background of the signage systems } \\
\text { (signs for food/drink facilities) }\end{array}$ & 4.00 & 1.069 \\
\hline & & $\begin{array}{l}\text { Use of simple and meaningful icons } \\
\text { and plain language on the signage } \\
\text { systems (signs for food/drink facilities) }\end{array}$ & 4.00 & 1.069 \\
\hline & & $\begin{array}{l}\text { Placement of signage system (signs for } \\
\text { food/drink facilities) }\end{array}$ & 1.75 & 0.886 \\
\hline & & Illumination level & 4.50 & 0.535 \\
\hline & & $\begin{array}{l}\text { Audible and understandable } \\
\text { announcements }\end{array}$ & 3.75 & 1.035 \\
\hline & & Amount of seating elements & 3.50 & 0.926 \\
\hline & & Comfort of seating elements & 4.25 & 0.707 \\
\hline
\end{tabular}

Table 2.

dependent variable. The results of the regression were illustrated in Table 3 . The $R^{2}$ of the multiple linear regression was 0.976 , which shows that $97 \%$ of the variance of the building element performance is explained by the extracted components. Table 3 also presents the relative importance of each building element to the ASP according to the value of coefficients. Therefore, the most important building element is horizontal circulation (1.009), followed by restrooms (0.856) and vertical circulation (0.684). 


\subsection{Perceived empathy}

Finally, at the end of the first three sessions, to evaluate the perceived empathy level of the experts towards older adults, the perceived closeness was assessed with the IOS Scale (Aron et al., 1992). The results of the $t$-test showed that the group with the GERT suit experienced higher perceived closeness (higher empathy) towards the older adults compared to the group without the GERT suit $(p=0.07)$.

\section{Discussion}

This study analysed the gathered data both qualitatively and quantitatively regarding the ASP. According to the comparison of the qualitative results obtained during the preinterview and post-interview, experts could not experience all of the ASP aspects within only one session. Service walkthrough and the ASP criteria enabled the experts to consider the case airport building in a more comprehensive way. The GERT suit also gave them the opportunity to experience empathy for the physical limitations of older passengers. During the post-test, experts mentioned more service problems even though the same open-ended questions of the pre-interview were asked.

The quantitative results of the study were also consistent with the qualitative results, where lower service performance scores were obtained. The highest ASP score was obtained by the restrooms. The restrooms were located over many areas of the airport building. Restroom cabins were quit large and their doors were opening to the outside. The faucets and soap dispensers were working with automatic sensors, so they did not require physical effort. The visibility of the restrooms was evaluated as positive by the participants in terms of their positioning and the directional signs. The average score of the overall ASP is 3.7851. Some improvements are required to increase the ASP of the case airport building. So, the findings of the study were shared with the airport administration as a report to suggest some necessary service improvements. Long walking distances, number of seating elements, content of the signage system and the placement of the vertical circulation elements were the least successful service sub-criterion. Accordingly, the authors advised the airport administration to start the improvement from these criteria. The airport administration took our suggestions into consideration and first, they added seating elements around the check-in counters as a short-term development. They mentioned that they would start the necessary actions on signage system as well. They also stated that there are buggy transfer services at the airport to shorten the long walking distances, and this service is free for the passengers over 65 years old. Apart from that, they also claimed that they would be reviewing each sub-criterion scores in a detailed manner.

On the other hand, the GERT suit in this study helped only simulating the physical limitations of older adults. Certainly, there are also some limitations in the cognitive capabilities of older adults as a result of normal their ageing process. Sensory and cognitive

\begin{tabular}{lrr}
\hline & $B$ & Standardized beta \\
\hline (Constant) & 3.296 & \\
Access & 0.329 & 0.284 \\
Horizontal circulation & 1.009 & 1.034 \\
Vertical circulation & 0.684 & 0.858 \\
Seating facilities & -2.437 & -2.468 \\
Restrooms & 0.856 & 0.924 \\
Eating and drinking facilities & -1.192 & -1.546
\end{tabular}
Airport
environment
performance

Note(s): $R=0.988, R^{2}=0.976$, adjusted $R^{2}=0.830$

Table 3. Building elements regression 
$\mathrm{ARCH}$ 15,3

920

components of aging should be also considered along their own lived experiences. Thus, further testing with real older adults as a third participant group of the study could be added for the wide applicability of the study. Furthermore, there is still much debate in the literature that the ageing is not a homogeneous process; there are early elderly (60-74 years) and late elderly (75 years and more) people (Kaur and Verma, 2007). Thus, the age range should be considered in terms of their physical performance. Further, during the experiment, the study participants had no real flight tickets; therefore, there was no time pressure for catching the flight since they had $1 \mathrm{~h}$ until the boarding. Therefore, they performed the tasks without feeling they are under a pressure. Thus, it is expected that passengers with real flight tickets could have different associations with the service quality. Future studies could focus on multiple assessments of other service methods in different building typologies, such as hospitals, shopping malls as well as outdoor natural landscapes. The ASP criteria mapped with universal design principles could be beneficial for generalizable findings. Besides, qualitative accounts of experience could generate important insights during service assessments. Future research is recommended to explore qualitative data in detail to supplement the findings of the current study. Moreover, conducting similar assessments along emphatic studies in various building typologies would be beneficial to transform the service performance of the architectural buildings and to achieve more liveable spaces not only for older adults but also for diverse user groups. ASP assessment models that can be applied effectively, efficiently and satisfactorily in the planning, design and evaluation are inevitable for built and urban environments.

\section{Conclusion}

This study is a pioneering study considering the two following aspects: (1) defining a new set of service criteria considering the needs of older passengers and architectural building elements and (2) evaluating the service performance of an airport building with the proposed SBSW method. Accordingly, this study suggested a new empathic methodology to increase designers' understanding towards needs and demands of older passengers to promote agefriendly service design. By restricting the physical capabilities of the experts with the suit, a more immersive service evaluation was obtained. These insights are important to holistically understand the service needs of older passengers. If designers do not put themselves into the user's shoes, there is a risk for ending up self-centred designed instead of user-centred.

In conclusion, how complex environments like airports could adapt their services effectively and efficiently to respond to the needs of all users is still a challenging question that should be focused on by the local practices, global design, policy systems and designers. This study is an initial attempt to overcome this challenge by exploring the diversity of user experiences through a simulation-based emphatic method. Future studies could investigate these experiences from the perspective of paradoxes of stakeholder priorities considering the complexity of service design.

\section{References}

Airports Council International (2000), Quality of Service at Airports, Standards and Measurements, Geneva.

Airports Council International (2008), "ASQ survey: benchmarking the global airport industry", available at: http://aci-na.org/static/entransit/ASQ_Brochure2008.pdf (accessed 10 October 2020).

Aron, A., Aron, E.N. and Smollan, D. (1992), "Inclusion of other in the self scale and the structure of interpersonal closeness", Journal of Personality and Social Psychology, Vol. 63 No. 4, pp. 596-612. 
Arvola, M., Blomkvist, J., Holmlid, S. and Pezone, G. (2013), "A service walkthrough in Astrid Lindgren's footsteps”, Service Design and Innovation Conference 2012, Helsinki.

Bezerra, G.C.L. and Gomes, C.F. (2015), "The effects of service quality dimensions and passenger characteristics on passenger's overall satisfaction with an airport", Journal of Air Transport Management, Vol. 44 No. 45, pp. 77-81, Elsevier.

Blomkvist, J. and Bode, A. (2012), "Using service walkthroughs to co-create whole service experiences: a prototyping technique for service design", Proceedings of the 3rd International Service Innovation Design Conference, Holistic Service Innovation and Co-Creation Experience, pp. 1-6.

Bogicevic, V., Yang, W., Bilgihan, A. and Bujisic, M. (2013), "Airport service quality drivers of passenger satisfaction”, Tourism Review, Vol. 68 No. 4, pp. 3-18.

Boletsis, C. (2018), "VR service walkthrough: a virtual reality-based method for service prototyping", ServDes2018, Milan, 18th-20th June 2018.

Bouwhuis, D.G. (1992), “Aging, perceptual and cognitive functioning and interactive equipment”, in Bouma, H. and Jan, G. (Eds), Gerontechnology, IOS Press, Amsterdam, pp. 93-112.

Buchenau, M. and Suri, J.F. (2000), "Experience prototyping", Proceedings of the Conference on Designing Interactive Systems: Processes, Practices, Methods, and Techniques, DIS. doi: 10.1145/ 347642.347802.

Burghouwt, G., de Wit, J. and van der Bruggen, J. (2006), The Impact of on Aviation, Airneth Report 3, Amsterdam.

Burns, C., Dishman, E., Verplank, W. and Lassiter, B. (1994), "Actors, hairdos and videotapeinformance design”, CHI'94 - Celebrating Independence, Boston, MA, pp. 119-120.

Chang, Y.C. and Chen, C.F. (2012), "Service needs of elderly air passengers", Journal of Air Transport Management, Elsevier, Vol. 18 No. 1, pp. 26-29.

Correia, A.R. and Wirasinghe, S.C. (2008), "Modeling airport landside performance", Transportation Research Part A, Vol. 42 No. 2008, doi: 10.1016/j.tra.2007.10.009.

da Silva, T.N.R., de Souza, J.B.G., Camarotto, J.A. and Menegon, N.L. (2018), in Sebastiano, B., Fujita, R., Sara, T., Thomas, A. and Alexander, Y. (Eds), "Passengers with disabilities, elderly and obese in Brazilian air transportation: contradictions in the activity systems", Proceedings of the 20th Congress of the International Ergonomics Association (IEA 2018), pp. 1747-1756.

de Barros, A.G., Somasundaraswaran, A.K. and Wirasinghe, S.C. (2007), "Evaluation of level of service for transfer passengers at airports", Journal of Air Transport Management, Vol. 13 No. 5, pp. 293-298.

Edwards, B. (2005), The Modern Airport Terminal: New Approaches to Airport Architecture, 2nd ed., Spon Press, New York, NY.

Elo, S. and Kyngäs, H. (2008), "The qualitative content analysis process", Journal of Advanced Nursing, Vol. 62 No. 1, pp. 107-115.

Erdil, S.T. and Yildiz, O. (2011), "Measuring service quality and a comparative analysis in the passenger carriage of airline industry", Procedia - Social and Behavioral Sciences, Vol. 24 No. 2011, pp. 1232-1242.

Eshtaiwi, M., Badi, I., Abdulshahed, A. and Erkan, T.E. (2018), "Determination of key performance indicators for measuring airport success: a case study in Libya", Journal of Air Transport Management, Elsevier, Vol. 68 No. 2018, pp. 28-34.

Eymard, A.S., Crawford, B.D. and Keller, T.M. (2010), "'Take a walk in my shoes': nursing students take a walk in older adults' shoes to increase knowledge and empathy", Geriatric Nursing, Vol. 31 No. 2, pp. 137-141.

Froyen, H. (2012), Universal Design, a Methodological Approach: A Pathway to Human-Friendly and Elegant Architecture, Institute for Human Centered Design, Boston, MA.

Gonçalves, M.W.E. and Caetano, M. (2017), "Airport level of service: a model according to departing passengers' perceptions at a small-sized airport", Journal of Airline and Airport Management, Vol. 7 No. 1, p. 65. 
$\mathrm{ARCH}$ 15,3
Graham, A., Budd, L., Ison, S. and Timmis, A. (2019), “Airports and ageing passengers: a study of the UK”, Research in Transportation Business and Management, Vol. 30, doi: 10.1016/j.rtbm.2019.100380.

Groza, H., Sebesi, S.B. and Mandru, D.S. (2017), "Age simulation suits for training, research and development”, IFMBE Proceedings. doi: 10.1007/978-3-319-52875-5_17.

Hall, T.C., Nixon, M.F., Dias, J.J., Graham, T. and Cook, S. (2010), "How accurately does a simulation glove reflect function compared to rheumatoid arthritis sufferers?", Annals of the Royal College of Surgeons of England, Vol. 92, pp. 605-609.

Hino, K., Usui, H. and Hanazato, M. (2020), "Three-year longitudinal association between built environmental factors and decline in older adults' step count: gaining insights for age-friendly urban planning and design", International Journal of Environmental Research and Public Health, Vol. 17 No. 12, pp. 1-11.

Ilg, J., Wuttke, C.C. and Siefert, A. (2018), "Systematic prototyping of product-service systems", Procedia CIRP, Elsevier B.V., Vol. 73 No. 2018, pp. 50-55.

Jiang, H. and Zhang, Y. (2016), "An assessment of passenger experience at Melbourne Airport", Journal of Air Transport Management, Elsevier, Vol. 54 No. 2016, pp. 88-92.

Kaario, P., Vaajakallio, K., Lehtinen, V., Kantola, V. and Kuikkaniemi, K. (2009), "Someone else's shoes - using role-playing games in user-centered service design”, First Nordic Conference on Service Design and Service Innovation, Oslo, 24th-26th Nov 2009.

Kaur, M.N. and Verma, S. (2007), Principles of Geriatric Physiotherapy, Jaypee Brothers, New Delhi. doi: $10.5005 / \mathrm{jp} /$ books/10676.

Kimbell, L. and New, S. (2013), "Chimps, designers, consultants and empathy: a 'theory of mind' for service design", Proceedings of the 2nd Cambridge Academic Design Management Conference, Cambridge, 4th-5th September 2013.

Kohijoki, A.M. and Marjanen, H. (2013), "The effect of age on shopping orientation-choice orientation types of the ageing shoppers", Journal of Retailing and Consumer Services, Elsevier, Vol. 20 No. 2, pp. 165-172.

Koseoglu, O., Sakin, M. and Arayici, Y. (2018), "Exploring the BIM and lean synergies in the Istanbul Grand Airport construction project", Engineering, Construction and Architectural Management, Vol. 25 No. 10, pp. 1339-1354.

Kouprie, M. and Visser, F.S. (2009), "A framework for empathy in design: stepping into and out of the user's life”, Journal of Engineering Design, Vol. 20 No. 5, pp. 437-448.

Lavallière, M., D’Ambrosio, L., Gennis, A., Burstein, A., Godfrey, K.M., Waerstad, H., Puleo, R.M., Lauenroth, A. and Coughlin, J.F. (2017), "Walking a mile in another's shoes: the impact of wearing an Age Suit”, Gerontology and Geriatrics Education, Routledge, Vol. 38 No. 2, pp. 171-187.

Lee, S. and Kline, R. (2011), "Wayfinding study in virtual environments : the elderly vs. the youngeraged groups", ArchNet-IJAR, Vol. 5 No. 2, pp. 63-76.

Lee, T.K., Hutter, J.N., Masel, J., Joya, C. and Whitman, T.J. (2017), "Guidelines for the prevention of travel-associated illness in older adults", Tropical Diseases, Travel Medicine and Vaccines, Vol. 3 No. 1, pp. 1-12.

Liou, J.J.H., Tang, C.H., Yeh, W.C. and Tsai, C.Y. (2011), "A decision rules approach for improvement of airport service quality", Expert Systems with Applications, Elsevier, Vol. 38 No. 11, pp. 13723-13730.

Magri, A.A. Jr and Alves, C.J.P. (2005), "Passenger terminals at Brazilian airports: an evaluation of quality", Journal of the Brazilian Air Transportation Research Society, Vol. 1, pp. 9-17.

McIntyre, L. and Harrison, I.R. (2017), "The effects of built environment design on opportunities for wellbeing in care homes", Archnet-IJAR, Vol. 11 No. 1, pp. 138-156. 
Mikulić, J. and Prebežac, D. (2008), "Prioritizing improvement of service attributes using impact rangeperformance analysis and impact-asymmetry analysis", Managing Service Quality, Vol. 18 No. 6, pp. 559-576.

Namkung, Y. and Jang, S.C.S. (2009), "The effects of interactional fairness on satisfaction and behavioral intentions: mature versus non-mature customers", International Journal of Hospitality Management, Vol. 28 No. 3, pp. 397-405.

National Research Council (U.S.), (2014), Impacts of aging travelers on airports, transportation research board, available at: http://vsgc.odu.edu/ACRPDesignCompetition/2015/Resources for Design Competion Website/acrp_syn_051_Impacts on Aging Travelers.pdf.

Oh, H., Parks, S.C. and Demicco, F.J. (2002), “Age-and gender-based market segmentation: a structural understanding", International Journal of Hospitality and Tourism Administration, Vol. 3 No. 1, pp. 1-20.

Pabedinskaite, A. and Akstinaite, V. (2014), "Evaluation of the airport service quality", Procedia Social and Behavioral Sciences, Vol. 110, No. 2014, pp. 398-409.

Parasuraman, A., Zeithaml, V.A. and Berry, L.L. (1988), "Servqual: a multiple-item scale for measuring consumer perception of service quality", Journal of Retailing, Vol. 64 No. 1, pp. 12-40.

Pastalan, L.A. (1974), "The simulation of age related sensory losses: a new approach to the study of environmental barriers", Journal of Visual Impairment and Blindness, Vol. 68 No. 8, pp. 356-362.

Pereira, T., Cipriano, I., Costa, T., Saraiva, M. and Martins, A. (2019), "Exercise, ageing and cognitive function - effects of a personalized physical exercise program in the cognitive function of older adults", Physiology and Behavior, Vol. 202, pp. 8-13.

Platt, D. (1991), Biologie Des Alterns Ein Handbuch, De Gruyter, Berlin.

Qing, Z., Sun, C. and Reneker, J. (2020), "Evaluation of airport wayfinding accessibility with the use of a wheelchair simulator", Transportation Research Record: Journal of the Transportation Research Board, Vol. ahead-of-print No. ahead-of-print, pp. 1-9.

Ramos-Sesma, V., Górgolas-Hernández Mora, M. and Ramos-Rincón, J.M. (2018), "The elderly traveler", Revista Clinica Española (English Edition), Vol. 218 No. 8, pp. 426-434.

Russell, J. (2019), "Can age suit simulation enable physiotherapy students to experience and understand the specific challenges to balance experienced by older adults?", Physiotherapy, The Chartered Society of Physiotherapy, Vol. 105, pp. e183-e184.

Saup, W. (1993), Alter Und Umwelt: Eine Einführung in Die Ökologische Gerontologie, W. Kohlhammer, Stuttgart.

Swaranjali, P., Patel, T. and Espersen-Peters, K. (2021), "Next time, with empathy: revisiting the studio pedagogy for transitional housing for refugees", Archnet-IJAR, Vol. ahead-of-print No. ahead-ofprint, doi: 10.1108/ARCH-08-2020-0173.

Tremayne, P., Burdett, J. and Utecht, C. (2011), "Simulation suit aids tailored care", Nursing Older People, Vol. 23 No. 7, pp. 19-22.

Wiredja, D., Popovic, V. and Blackler, A. (2019), "A passenger-centred model in assessing airport service performance", Journal of Modelling in Management, Vol. 14 No. 2, pp. 492-520.

World Health Organization (2007), "Global age-friendly cities: a guide, community health", available at: http://whqlibdoc.who.int/publications/2007/9789241547307_eng.pdf?ua=1.

Yeh, C.H. and Kuo, Y.L. (2003), "Evaluating passenger services of Asia-Pacific international airports", Transportation Research Part E: Logistics and Transportation Review, Vol. 39 No. 1, pp. 35-48.

Zijlstra, E., Hagedoorn, M., Krijnen, W.P., van der Schans, C.P. and Mobach, M.P. (2016), "Route complexity and simulated physical ageing negatively influence wayfinding", Applied Ergonomics, Vol. 56, pp. 62-67. 
$\mathrm{ARCH}$ 15,3

924
Zomerdijk, L.G. and Voss, C.A. (2011), "NSD processes and practices in experiential services", Journal of Product Innovation Management, Vol. 28, pp. 63-80.

\section{About the authors}

Irem Caglayan is a $\mathrm{PhD}$ Candidate in the Department of Interior Architecture and Environmental Design at Bilkent University. She has a Bachelor and Master of Fine Arts in interior architecture and environmental design from Bilkent University. Her research interests focus on age-friendly design, service design, usability and walkability. She is currently working with Dr. Afacan on walkability modelling of interior environments. Irem Caglayan is the corresponding author and can be contacted at: irem.yumusak@bilkent.edu.tr

Yasemin Afacan received her Ph.D. degree in the Department of Interior Architecture and Environmental Design from Bilkent University in 2008. After working as a lecturer at the Queens University of Belfast, School of Planning in the Department of Architecture and Civil Engineering, Dr. Afacan joined Bilkent University Department of Interior Architecture and Environmental Design in 2011 as a faculty member. She is the department chair, vice director of Graduate School of Economics and Social Sicences. She has won the Outstanding Young Scientists Awards in architecture by the Science Academy of Turkey (BAGEP-2017) and Turkish Academy of Sciences (GEBIP-2018).

For instructions on how to order reprints of this article, please visit our website: www.emeraldgrouppublishing.com/licensing/reprints.htm Or contact us for further details: permissions@emeraldinsight.com 